PERSPECTIVA TEOLÓGICA ADERE A UMA LICENÇA CREATIVE

COMMONS ATRIBUIÇÃO 4.0 INTERNACIONAL - (CC BY 4.0)

\title{
DIGNITATIS HUMANAE, THE FUTURE OF RELIGIOUS FREEDOM AND THE GLOBAL COMMOM GOOD *
}

Dignitatis humanae, o futuro da liberdade religiosa e o bem comum universal

Linda Hogan **

\begin{abstract}
Our global and local conversations about human dignity and flourishing are shaped by the irreducible plurality of human experience, including religious experience and our political cultures must have the capacity to facilitate intercultural and interreligious exchange. In this context it is more vital than ever that religious traditions, including Catholicism, are to the fore as we go about the business of building a politics focused on the global common good. From the perspective of Catholicism, the contribution of Dignitatis humanae has yet to be properly realised, not only in respect to respect for religious pluralism, but more especially in respect to ethical pluralism.
\end{abstract}

KEYWORDS: Dignitatis humanae. Globalisation. Religious Pluralism. Ethical Pluralism. Common Good.

RESUMO: Nossas conversações locais e globais sobre a dignidade humana e a prosperidade são determinadas pela irredutível pluralidade da experiência humana, inclusive a experiência religiosa e nossas culturas políticas devem ter a capacidade de facilitar os intercâmbios interculturais e interreligiosos. Neste contexto, é mais vital do que nunca que as tradições religiosas, inclusive o Catolicismo, estejam em primeiro plano, pois nosso interesse é a construção de políticas centradas no bem comum. Na perspectiva do Catolicismo, a contribuição de Dignitatis Humanae ainda não se realizou adequadamente, não só no que se refere ao pluralismo religioso, mas especialmente no diz respeito ao pluralismo ético.

PALAVRAS-CHAVE: Dignidade humana. Globalização. Pluralismo religioso. Pluralismo ético. Bem comum.

\footnotetext{
* This text was presented at Georgetown University in 2015 and that the video of the lecture is available at https://www.youtube.com/watch? $\mathrm{v}=0 \mathrm{HgBHh}$ - $9 \mathrm{~L} 8$.

** Trinity College Dublin, Dublin 2, Ireland.
} 


\section{Introduction}

$\mathrm{O}$ ur collective fate is more closely tied than at any time in our history. Almost daily we encounter issues that no government can successfully deal with alone - global degradation, nuclear and chemical proliferation, migration, terrorism - and so it is more important than ever that we create a global politics premised on the protection of human dignity and flourishing. The creation of such an emancipatory politics is vital for our planetary wellbeing and religious traditions have the potential to play a significant role in this task. The creation of an emancipatory politics is a complex and multi-faceted project, on which political scientists and legal scholars have deliberated for decades. However, it is my contention that such a politics cannot be created through the classic liberal model of agreement by avoidance, but can only be constructed through inclusive, tradition-thick, cross-cultural and multi-religious conversations through which human dignity can be secured and agreement on contested issues can be pursued.

Given that our global and local conversations about human dignity and flourishing are shaped by the irreducible plurality of human experience, including religious experience, our political cultures must have the capacity to facilitate such intercultural and interreligious exchange. Of equal importance however is the capacity of religious traditions to be part of this deliberative process, a process in which there is mutual respect for the convictions, including the religious convictions of the other, and in which there is a mutual appreciation of the ethical values embedded in these discrete and varied traditions.Indeed since religious pluralism has become entangled with the politics of fear which has threatened to undermine the toleration that has been achieved in many parts of the world, and which threatens to further inflame cultural and religious disagreements where discord already exist (NUSSBAUM, 2012, p.7) it is even more vital than ever that religious traditions, including Catholicism, are to the fore as we go about the business of building a politics focused on the global common good. And from the perspective of a theological ethicist, it is here that one sees a crucial dimension of the unfinished agenda of Dignitatis humanae, one that is vital not only for the church but for the global common good.

Dignitatis humanae was finally approved on December $7^{\text {th }} 1965$, the last working day of the Second Vatican Council. It was remarkable accomplishment, both politically and theologically, and the final vote of 2,308 in favour and 70 opposed belies the depth and extent of the opposition that it initially faced. Moreover, its influence has been transformative, and its agenda is as vital today as it was on the day of its promulgation. It created a new theological context from which the church has been able to engage with the reality of religious and cultural pluralism, and I will discuss this in the first part of my paper. I will then briefly discuss the 
nature of global politics today in order to demonstrate why it is more important than ever that the church continues to reckon with religious pluralism and to affirm its value. In this context I will then suggest that Dignitatis humanae has only just begun a process that must be continued, highlighting in particular that an important and neglected part of unfinished agenda of Dignitatis humanae relates to how the church engages the ethical truth claims (as well as the religious truth claims) of the other. Thus, I will argue that the same trajectory in respect of ethical pluralism needs to be pursued, as has been adopted in respect of religious truth claims, if the church is to be a credible voice in articulating a vision of the global public good in a pluralistic world.

\section{Dignitatis humanae in its historical and theological context}

Dignitatis humanae made a remarkable journey, from its origins as the final chapter in the initial draft of De Ecclesia ${ }^{1}$ to its position as one of the most celebrated documents of a Council that itself was ground-breaking. It is all the more remarkable however when one understands both the immediate and historical context of its promulgation. Dignitatis humanae opened with the acknowledgement that "people nowadays are becoming increasingly conscious of the dignity of the human person, a growing number demand that people should exercise fully their own judgment and responsible freedom in their actions and should not be subject to external pressure of coercion but inspired by a sense of duty. At the same time to prevent excessive restrictions of the rightful freedom of individuals and they demand constitutional limitation of the powers of government." (DH, n. 1 forthwith) The Council declared these demands to be "greatly in accord with truth and justice" (DH, n. 1) and moved immediately, in paragraph 2 , to declare unambiguously that:

the human person has a right to religious freedom. Freedom of this kind means that everyone should be immune from coercion by individuals or social groups and every human power, so that within due limits no men or women are forced to act against their convictions nor are any persons to be restrained from acting, in private or in public, in accordance with their convictions in religious matters (DH, n. 2).

The Council further declared that the right to religious freedom "is based on the very dignity of the human person as known through the revealed

${ }^{1}$ This chapter was never presented to the Council for debate as is discussed by Thomas Stransky, in his Declaration on Religious Freedom, A Commentary p. 17-18 on whose analysis I have relied in this section of the essay. 
word of God and by reason itself. This right of the human person to religious freedom must be given such recognition in the constitutional order of society as well make it a civil right" (DH, n. 2).

Fifty years on from its promulgation, and almost 70 years on from the United Nations Declaration of Human Rights such an affirmation, although welcome, may not seem particularly ground-breaking or controversial. This is especially likely to be the case in the US context where even in 1965 Dignitatis humanae effectively described the modus operandi of the US church in respect of the State, and the State in respect of the church. In 1965 however, in the historical and theological context of its promulgation, it was both ground-breaking and controversial. A great deal of energy has been expended in the debate about whether Dignitatis humanae's confirmation of the right to religious freedom and the obligation on states to legislate for that, represented an evolution or a revolution in the Church's teaching on religious freedom. Whether evolution or revolution, however, it did represent a significant change from the political posture that the church had adopted during the long nineteenth century and it opened the way for a gradual evolution in the church's theological assessment of other religious traditions.

The shape of the church's thinking on religious liberty evolved over many centuries. The Constantinian era inaugurated an approach which assumed that unity in religion was essential for political peace and stability, and it was only post the Reformation in Europe when the Peace of Westphalia (1648) established the political arrangement of cuius regio, eius religio that the issue of the political right to the free expression of religion began to be explicitly, if only occasionally, discussed. The issue gathered pace in the post-Enlightenment period but the manner in which it was debated varied in different political contexts and depended on the extent to which religious and political identities converged or diverged, on the presence or not of minorities, on the extent and rate of migration, and on the political and legal structures in the different states.

The immediate reaction of the Catholic church to the political philosophy of the French revolution is well known. Not only did Pius VI declare that it was anathema for Catholics to accept the 1789 Declaration of the Rights of Man and of the Citizen, stating that "this equality, this liberty, so highly exalted by the National Assembly, have then as their only result the overthrow of the Catholic religion" (PLONGERON, 1979, p.7), but Gregory XVI's 1832 encyclical Mirarivos also strongly condemned liberalism, individualism, democracy, and also freedom of conscience, of speech, and of the press (CARLEN, 1990, p.198). Pius IX's 1864 Syllabus of Errors (published alongside his encyclical Quanta Cura) reinforced this further and listed a set of erroneous propositions, amongst which were the beliefs that: every man is free to embrace and profess that religion which, guided by 
the light of reason, he shall consider true, ${ }^{2}$ that the Church ought to be separated from the State, and the State from the Church, ${ }^{3}$ and that in the present day it is no longer expedient that the Catholic religion should be held as the only religion of the State, to the exclusion of all other forms of worship. ${ }^{4}$ Thus well into the twentieth century one could be in no doubt that, both theologically and politically, there was no recognition of the right to religious freedom. In fact it was explicitly rejected.

The twentieth century saw significant theological and political debate about the relationship between church and state (as it was called), driven primarily by theologians and to a lesser extent Conferences of Bishops in jurisdictions that were de facto pluralistic (USA, Canada, United Kingdom, and parts of continental Europe).There was particular unhappiness with the contradiction, one might even say hypocrisy of, on the one hand the church promoting human dignity and constitutional government, and on the other holding fast to the idea that where the Catholic church was the majority church, then the state should not tolerate other religions. Many theologians and Catholic politicians believed that this was an embarrassment to the church that could no longer be tolerated, and through the 1950s and 60s theologians like John Courtney Murray, Jacques Maritain began to develop the theological principles that would allow the church to draw on other aspects of the tradition to affirm religious freedom as a right. Others who were concerned with ecumenical and inter-faith relations, including Johannes Willebrands, Yves Congar, and Gustav Weigel also developed the theological discussion in other important directions.

Dignitatis humanae made two essential theological claims, both of which were already present in the tradition, but which were given particular prominence such that they enabled the bold and positive statement on religious freedom against the immediate backdrop that seemed to exclude such a position. First it claimed that by virtue of their being imago Dei, human beings have an inherent dignity and a calling to seek and follow the truth, that this is made manifest to them through their consciences, and that no government could obstruct this as long as it did not impinge on the common good. And second it insisted that the act of faith must be free and sincere, and the freedom to follow one's conscience on matters of faith is possessed by everyone. Pacem in Terris (PT), issued in 1963, had already effected an important evolution in respect of the right to freedom of religion, and indeed did so by drawing on the same theological resources. Pacem in Terris included the right to freedom "in searching for truth" and the right "to honor God according to the sincere dictates of

2 Allocution "Maxima quidem," June 9, 1862; Damnatio "Multiplices inter," June 10, 1851, apud STRANSKY, 1967, p. 15.

${ }^{3}$ Allocution "Acerbissimum," Sept. 27, 1852, apud STRANSKY, 1967, p. 55.

${ }^{4}$ Allocution "Nemo vestrum" July 26, 1855, apud STRANSKY, 1967, p. 77. 
[one's] own conscience" (PT, n. 14) amongst the rights to which all human beings are entitled, and proclaimed that human rights flow "directly and simultaneously from the nature of the person" and are "universal and inviolable" (PT, n. 9). Moreover it had also asserted the value and viability of the language of human rights as the way to protect human dignity in the political sphere.

There was deep opposition to Dignitatis humanae as it was being debated during the Council. This opposition, which it eventually withstood, focused on two main objections. The first was that it represented a significant change in church teaching. The second was that the commitment to religious freedom as a value that flowed from the dignity of the human person would foster subjectivism and religious indifferentism, and that it ran counter to the position that the Catholic church is the only church of Jesus Christ. Of course it is important to acknowledge that there is an ambivalence inherent in the document, as it relates to the right to religious freedom. True, Dignitatis humanae asserts that "it is in accordance with their dignity that all human beings because they are persons endowed with reason and free will and therefore bearing personal responsibility are therefore impelled by nature and bound by a moral obligation to seek the truth, especially religious truth. They are also bound to adhere to the truth, once it is known, and to order their whole lives in accord with the demands of truth." (DH, n. 2). However it also, in parallel, asserts that "this leaves untouched traditional Catholic teaching on the moral obligation of individuals and societies toward the true religion and toward the one Church of Christ." (DH, n. 1). And while one can accept that there is no logical or necessary conflict between these two assertions, nonetheless they represent two different trajectories in terms of the epistemological and theological core of the tradition, the one gesturing towards an inclusivist approach, the other towards a more exclusivist one. Indeed a comparable ambivalence can be seen in many of the other Council documents and also in the politics of their reception in the tradition, especially in relation to how the primacy of conscience is treated. Thus Gaudium et spes for example speaks of conscience as the person's "most secret core, and their sanctuary", and affirms that "deep within their consciences men and women discover a law which they have not laid upon themselves and which they must obey" (GS, n. 16), an articulation that chimes with Dignitatis humanae's statement that "all men are bound to seek the truth, ... and to embrace it and hold on to it as they come to know it" (DH, n. 1). By contrast Veritatis splendor defends an objectivist and exclusivist approach to moral truth when it asserts that "the Church has the right always and everywhere to proclaim moral principles, even in respect of the social order, and to make judgments about any human matter" (Canon 747, apud Veritatis Splendor, n. 27) a position that chimes with Dignitatis humanae's statement about the moral duty of men and societies toward the true religion. 
There is no doubt however that those who objected to Dignitatis humanae on these grounds were correct in seeing where the significance of the Declaration lay. The recognition that the right to religious freedom is a cornerstone of a just society was indeed a departure for the church, especially, but not only in lands where the majority population was Catholic. It did pave the way for an evolution in how the post-Vatican II church approached the crucial issue of religious pluralism, although for the most part the impact of the evolution is seen much more clearly in how the church engages with the plurality of religious beliefs, but not as evident in how it contends with the pluralism of values. However, whether an instance of aggiornamento, of development, or of ressourcement, to reference John O'Malley's characterisation, (O'MALLEY, 2008) and notwithstanding the more traditional assertions about Catholicism as the one Church of Christ, there is no getting away from the fact that the church was set on a very different path in respect to pluralism in the aftermath of Dignitatis humanae.

\section{Dignitatis humanae in an age of religious revival and of political religion}

During the years when the Second Vatican Council was in session sociologists and political theorists were theorizing about the growth of secularization and its likely impact across the globe. The expectation at that time was that as economic development progressed, religion would become ever-more marginal in the lives of citizens. However trends over the last two decades suggest otherwise. Indeed The Future of World Religions: Population Growth Projections, 2010-2050 report, published by the Pew Research Centre (PEW, 2015) suggests, not only that the decline has been halted, but also that religion will continue to be a phenomenon with which to be reckoned for decades to come. The Report projects how the global religious landscape will look by the year 2050 if current trends in demographics continue, incorporating patterns of religious switching (including disaffiliation/exit) and migration, and it shows that those with a religious affiliation will make up an increasing share of the world's total population. However we also know that the trajectory is a complex one, and is not adequately captured through the simple categories of religiosity or secularism, since, as the 2014 Pew Report on Global Religious Diversity suggests, religious diversity within and across countries is also an extremely important feature of the global religious and political landscape (PEW, 2014). Of course human beings have always lived in the midst of diversity: religious, moral and political. Nonetheless as Charles Taylor's A Secular Age highlights, and as the Pew data suggests, what is distinctive about contemporary pluralism is that it is not just one factor amongst others, but rather it is the determinative feature of late modernity (TAYLOR, 2007, p. 3). 
It is further complicated moreover by what Jose Casanova has described as the de-privatization of religion, and the related phenomenon of the re-politicization of the private religious and moral sphere, (CASANOVA, 1994, p. 3) each of which has accelerated in the last two decades, and the impact of which has been felt across the globe, not only in the political sphere. Thus, religious believers, like other citizens, expect to have the opportunity to express their views on matters of critical public interest in the context of the accepted deliberative processes of the polis. They also often expect the religious institutions to which they belong to play a role in influencing public policy on issues of ethical, social and political significance. Moreover the issues of greatest concern to citizens (whether they belong to religious traditions or not) and on which they seek to influence policy decisions, are often those that are construed as belonging to the private religious and moral sphere. However, this distinction is unhelpful as it relates to the political manifestations of religious or other comprehensive doctrines, since when one considers the pivotal issues on which debates about the political influence of religion revolve, one can see that few issues are more obviously simultaneously political and private than a living wage, abortion, marriage equality, migration policy. It is inevitable that citizens, motivated by different theological and philosophical world-views, will forward a diversity of perspectives on the meaning and purpose of human existence, on the values by which individuals ought to live their lives and on the nature of the human goods by which a society ought to order itself. Given the likely incommensurability of some of these conceptualizations of the good, a crucial question therefore is how a political community can be built amongst people with diverse religious and philosophical commitments, and from the perspective of the Catholic tradition, the crucial question relates to the resources we have to engage with, or even be at the vanguard of this ethical project. And it is here that one can see the potential of Dignitatis humanae.

\section{Freedom of religion, ethical pluralism and the global common good}

Dignitatis humanae, perhaps more explicitly than any of the other Council documents, recognises that diversity is structured into our nature as human beings, and from its claims can be read a recognition of the goodness and the integrity of the different moral and religious traditions. This may be a contested reading, or perhaps it is more accurate to say that it may be regarded as an over-interpretation of the Declaration, and indeed the history of the reception of Dignitatis humanae would suggest that this is the case. Notwithstanding the ambivalence inherent in the document however, Dignitatis humanae did indeed effect a significant transformation in the 
church's approach to religious pluralism, and much progress has been seen in this regard in the last five decades. It has also created the conditions for a new way of engaging the deep ethical pluralism that characterizes contemporary life, and this, from the perspective of an ethicist, is a most crucial dimension of the unfinished agenda of the Declaration, and in some senses has been the most neglected.

Dignitatis humanae tells us that "it is in accordance with their dignity that all human beings because they are persons endowed with reason and free will and therefore bearing personal responsibility are therefore impelled by nature and bound by a moral obligation to seek the truth, especially religious truth" and that "the search for truth must be carried out in a manner that is appropriate to the dignity and social nature of the human person"... "by free enquiry with the help of teaching or instruction, communication and dialogue, it is by these means that people share with each other the truth they have discovered, or think they have discovered, in such a way that they help one another in the search for truth" and "the human person sees and recognizes the demands of the divine law through conscience" (DH, n. 3).

Indeed there are many other conciliar texts, particularly in Gaudium et spes that advance this approach. Indeed the texts of Dignitatis humanae and Gaudium et spes and their reception in the post-Vatican II church have played a formative role in effecting an evolution in the way in which the nature of moral truth and the discernment of conscience have been understood. Thus in the post-Vatican II era, and as a result of the Council, there has been a move away from the act-centered, legalistic, objectivist moral theology of neo-Scholasticism, towards more biblically-based, historicallyconscious, context-sensitive frameworks. This has had profound ramifications for how the church understands the nature of moral truth and how the person comes to understand and apprehend moral truth. It also has untapped potential in terms of the church's approach to ethical pluralism. ${ }^{5}$ It must be acknowledged however that although Vatican II inaugurated a paradigm shift in this regard, it has been deeply contested. One strand of the tradition stresses the objectivist, exclusivist and universalist nature of the moral truth, and the other has stressed its more contextual, pluralist nature. Nonetheless in the post-Vatican II church, influenced by texts like Dignitatis humanae and Gaudium et spes and reinforced further by feminist and post-colonial voices, there has been a much greater appreciation of the formative role that the person's historical and cultural positioning plays in how human beings come to know the truth, and a recognition that traditional universalist moral frameworks are replete with hidden assumptions about what is good and right and natural for human beings.

\footnotetext{
${ }^{5}$ See James Keenan's seminal A History of Catholic Moral Theology in the Twentieth Century: From Confession of Sins to Liberating Consciences. London \& New York: Continuum, 2010.
} 
A contextualist, situated model of moral truth and knowledge recognises that our moral reasoning is tradition-dependent, that we are creatures of tradition and history and our expressions of value, our accounts of the good life, our apprehension of the virtues, our practical reasoning about how to live a dignified life, these and all our other deeply held convictions emerge from the communities we inhabit and become our own through the world-views we encounter, and through the narratives we construct and reconstruct. Within such a moral framework the discernment of conscience is properly cognisant of the fact that it is shaped by context and cultural inheritance, as well as by socio-political and other factors. We are formed in the context of communities, within the currents of discursive traditions, and through our interactions with the world around us. Our moral claims emanate from and reflect this situatedness and are expressed through our indigenous languages. Moreover when we justify (explain) our moral positions to others and when we seek to adjudicate amongst competing moral positions we do so against this backdrop. Inevitably, when we admit the contingency of our moral knowledge and therefore of our moral judgments and claims of conscience, the issue of subjectivism and relativism is raised. Many continue to worry that once the contingency of moral knowledge is conceded there will be no firm ground on which to stand and from where one's moral values can be established and defended. Indeed this is precisely what Dignitatis humanae worried about and tried to avert through the parallel statement that the recognition of the obligation to seek the truth and to follow one's conscience left untouched the moral duty of men towards the true religion. However such an anxiety is misplaced since, it is possible to acknowledge that rationality is contingent and that justification is always contextual without also endorsing a relativist position in respect to truth. Rather, one can defend an ethical framework that is simultaneously realist in respect to truth, while contextualist in terms of justification. ${ }^{6}$

The revisionist strand in theology of the post-Vatican II church provides a particularly sophisticated and nuanced framework in which this approach to justification and adjudication in ethics can be advanced. It acknowledges that our ethical discourse, with its values and commitments, is constructed and narrated through the cultural and religious worlds that we inhabit, and it proceeds with the recognition that our values emanate from such moral contexts. In so doing, moreover, it allows for, indeed encourages, the church to engage in the kind of ethical debate which is vital to our global well-being. Importantly however this does not mean that we have to give up on the idea of the truth of our moral positions and of the rightfulness of our moral convictions. Nor does it mean that we must give

\footnotetext{
${ }^{6}$ For many centuries philosophers have debated the question of justification in ethics. The fundamental question is whether ethical and value judgments can be proved or justified in any objective way similar to the way in which our factual judgments can be justified. There are many different answers to this question of how one's moral judgments may be justified. I am persuaded by the contextualist position, and endorse value pluralism.
} 
up on the conviction that certain claims have a purchase that is wider than the contexts from which they have originated. We can indeed defend moral realism while also acknowledging the embedded character of our moral understanding. However the moral realism on which finite human beings can depend is a fractured realism. It is a realism that is based on an acknowledgement that, while our identities are shaped by the material and discursive conditions of our lives, and while the ethical judgments we make are inevitably shaped by the historical and religious contexts of our moral formation, we can nonetheless strive to embody the virtues and excellences that we have come to believe reflect the best that human beings can be. It means that we must be prepared to explain, justify and defend the conviction that the way we treat one another matters, that human beings have an inherent dignity, that our social order and political structures must function to promote this dignity, and that those who are especially vulnerable must be the focus of particular concern and protection.

Any durable consensus on fundamental values will have to reckon with the deep religious and ethical plurality that inevitably shapes our conversations (both global and local) about how human dignity can best be protected. For Catholicism the approach suggested and enabled by Dignitatis humanae has great, still untapped, potential in terms of allowing us to have a different kind of conversation about why certain of our views are so deeply held, what fundamental values they express and why they are of such elementary significance. In this context Dignitatis humanae has only just begun a process that must be continued if the church is to be a credible voice in articulating a vision of the global public good in a pluralistic world.

\section{References}

CARLEN, C. (Ed.). The Papal Encyclicals 1740-1878. Wilmington NC: Pierian Press, 1990. v. 1.

CASANOVA, J. Public Religions in the Modern World. Chicago: University of Chicago Press, 1994.

FLANNERY, A. The Basic Sixteen Documents Vatican Council II Constitutions, Decrees, Declarations: a Completely Revised Translation in Inclusive Language. Dublin: Dominican Publications, 1996.

GREGORY XVI. Mirarivos. In.: CARLEN, C. (Ed.). The Papal Encyclicals 1740-1878. Wilmington NC: Pierian Press, 1990. v. 1.

IOANNES PAULUS II, Pope. Veritatis splendour. Available in:<http://w2.vatican. va/content/john-paul-ii/en/encyclicals/documents/hf_jp-ii_enc_06081993_veritatissplendor.html>.

JOHN XXIII, Pope. Pacem in terris: Encyclical of Pope John XXIII on Establishing Universal Peace in Truth, Justice, Charity and Liberty - April 11, 1963. Available 
in: <http://w2.vatican.va/content/john-xxiii/en/encyclicals/documents/hf_j-xxiii_ enc_11041963_pacem.html>.

KEENAN, J. A History of Catholic Moral Theology in the Twentieth Century: from Confession of Sins to Liberating Consciences. London \& New York: Continuum, 2010.

NUSSBAUM, M. The New Religious Intolerance: Overcoming the Politics of Fear. Cambridge, MA: Belknap Press of Harvard University, 2012.

O' MALLEY, J. What Happened at Vatican II. Cambridge Mass.: Harvard University Press, 2008.

PAUL VI, Pope. Declaration on Religious Freedom Dignitatis humanae on the right of the Person and of Communities to Social and Civil Freedon in Matters Religious Promulgated by his Holiness Pope Paul VI on December 7, 1965. Available in: <http://www.vatican.va/archive/hist_councils/ii_vatican_council/documents/vatii_decl_19651207_dignitatis-humanae_en.html>.

. Pastoral Constitution on the Church in the Modern World Gaudium et Spes promulgated by his Holiness, Pope Paul VI on December 7, 1965. Available in: <http://www.vatican.va/archive/hist_councils/ii_vatican_council/documents/vatii_const_19651207_gaudium-et-spes_en.html>.

PEW RESEARCH CENTRE. The Future of World Religions: Population Growth Projections, 2010-2050, full report available at:<http://www.pewforum.org/2015/04/02/ religious-projections-2010-2050/>. Updated in 2017 to 2060.

. Global Religious Diversity: Half the Most Religiously Diverse Countries Are in Asia-Pacific Region. April 2014. Available in: <http://www.pewforum.org/2014/04/04/ global-religious-diversity/>.

PLONGERON, B. Anathema or Dialogue? Christian Reactions to the Declarations of the Rights of Man in the United States and Europe in the Eighteenth Century. In: MULLER, Alois; GREINACHER, Norbert (Eds). The Church and the Rights of Man. New York: Seabury Press, 1979. p. 1-16. (Concilium,12).

STRANSKY, T. Declaration on Religious Freedom: a Commentary. New York: Paulist Press, 1967.

TAYLOR, C. Secular Age. Cambridge, Mass.: Belknap Press of Harvard University Press, 2007.

Article submitted in 22 May 2018 and accepted in 04 July 2018.

Linda Hogan is PhD from Trinity College Dublin, 1993. Professor of Ecumenics at Trinity College Dublin. Orcid.org/0000-0003-4785-3724. Email: lhogan2@tcd.ie

Address: School of Religion

ISE/Loyola Building

Trinity College Dublin

Dublin 2 